\title{
Sabina Kauf
}

Universitas Opoliensis

e-mail: skauf@uni.opole.pl

ORCID: 0000-0002-5978-4490

\section{A SMART SUSTAINABLE CITY: THE CHALLENGES FACING SUSTAINABLE MOBILITY ZRÓWNOWAŻONA MOBILNOŚĆ JAKO WYZNACZNIK SMART CITY}

DOI: $10.15611 / \mathrm{pn} .2019 .7 .18$

JEL Classification: A1, H5, M3, N7, R4

Summary: The article presents issues related to creating sustainable mobility, which is one of the main elements of a smart city, the understanding of which in recent years has changed dramatically. We can observe a departure from the strictly technological understanding of a smart city, in favour of creative development and providing incentives for shaping urban space that is not only public, but also respects the requirements of the environment. This aspect is also necessary for the development of smart and sustainable mobility. The aim of this study is to identify the main premise and the characteristics of a smart and sustainable city, and to present mobility as one of the key challenges involved in the operationalization of the concept. Although the issue of a smart city and sustainable city in the literature is often taken up, their combination is less explored. These considerations start with presenting the key components of a smart sustainable city. This will allow to understand the idea of the concept. Next, we will go to the issue of mobility, which plays an important role in creating a smart sustainable city.

Keywords: sustainability, a smart city, smart mobility.

Streszczenie: Artykuł prezentuje zagadnienia związane z kreowaniem zrównoważonej mobilności, która jest jednym z głównych elementów smart city. Obserwujemy odejście od stricte technologicznego rozumowania miasta inteligentnego na rzecz kreatywnego rozwoju i dostarczania bodźców do kształtowania przestrzeni miejskiej, odpowiadającej nie tylko społeczeństwu, ale respektującej wymagania środowiska. Aspekt ten jest niezbędny dla rozwoju inteligentnej i zrównoważonej mobilności. Za cel opracowania przyjęto identyfikację założeń oraz cech miasta inteligentnego i zrównoważonego, a także przedstawienie mobilności jako jednego z kluczowych wyzwań smart sustainable city. Rozważania rozpoczniemy od przedstawienia głównych elementów miasta inteligentnego i zrównoważonego. Pozwoli to zrozumieć ideę koncepcji smart sustainable city. Następnie przejdziemy do kwestii mobilności, która odgrywa ważną rolę w operacjonalizacji koncepcji.

Keywords: zrównoważony rozwój, inteligentne miasta, inteligentna mobilność. 


\section{Introduction}

The growing ecological awareness and concern for the natural environment, combined with the increasing processes of urbanization and digitization, have created the need for a new view on city management, one that allows to reconcile the problems arising from the growing numbers of urban populations, the pursuit of economic growth and technological development. A smart sustainable city is a concept that combines all these aspects.

The aim of this study is to identify the main premise and characteristics of a smart and sustainable city, and to present mobility as one of the key challenges involved in the operationalization of the concept. Although the issue of a smart and sustainable city is often taken in the literature, their combination is less explored. We start the considerations by presenting the key components of a smart sustainable city. This will allow to understand the idea of the concept, next is the issue of mobility, which plays an important role in creating a smart sustainable city. In the summary will refer to the set goals.

\section{Premise for the development of a smart sustainable city}

The globalization of environmental problems and sustainable development is one of the key reasons for developing the concept of a smart sustainable city. Back in the 1970s, ecological issues were perceived only at a local level because they caused mostly local effects. Recent decades have shown that the problem is much broader. Climate change is observed globally and is a consequence of human activity and the excessive use of natural resources. We are observing a decline in biodiversity, land use change, ocean acidification, etc. Environmental changes require global solutions, not just local ones, which is reflected in the postulate of Agenda 21 "think global, act local"1.

The development of the concept of a smart sustainable city is a consequence of the urbanization and economic development of cities. Currently, the growth rate of cities is enormous. At the beginning of the 19 th century less than $1 \%$ of the population lived in cities. In one hundred years this percentage increased to $13 \%$, and at the turn of the century amounted to $47 \%$.

It is expected that this percentage will reach $68 \%$ by 2050 . The probable rate of urban growth is estimated at $1.9 \%$ by 2020 [Esa 2018], which is particularly evident in developing countries.

Cities inhabited by more than half of the world's population occupy only $2 \%$ of the surface of the Earth, resulting in their extensive overpopulation and negative

\footnotetext{
${ }^{1}$ Agenda 21 is a document that presents how to develop and implement sustainable development programs into local life. This document was adopted at the "Environment and Development" conference at the initiative of the United Nations in 1992 at the Second Conference in Rio de Janeiro.
} 


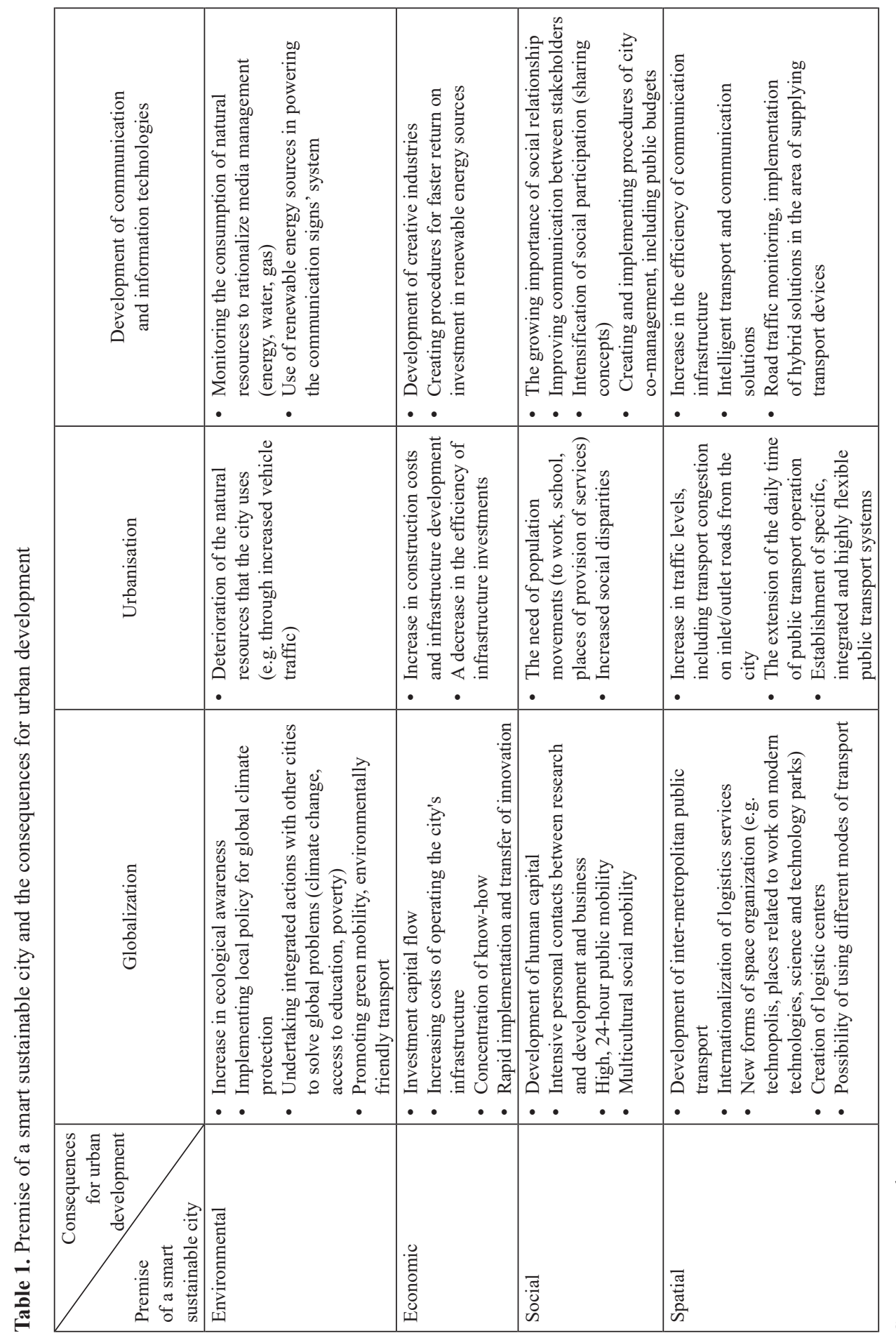

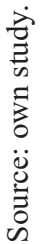


effects on the natural environment. A growing number of urban residents excessively use natural resources, produce large amounts of municipal waste, cause increases in greenhouse gas emissions, excessive exploitation of fuels and air pollution, resulting in smog. The trend associated with the permanent increase in the number of urban population and the "production" of economic growth $-65 \%$ of global GDP is generated in cities - indicates the need for effective and integrated city planning, as well as creating new concepts for their development. As a result, the concept of a sustainable city development has appeared.

A sustainable urban development is a necessary condition (but not sufficient) for sustainable development, considered on a global scale. The growing interest in this issue is reflected not only in the scientific discourse ${ }^{2}$, but also in the practical functioning of a city ${ }^{3}$. Pro-ecological solutions are increasingly applied, especially in the area of city infrastructure, public transport and waste management in a city.

The development of communication and information technologies has considerable importance for the sustainable development of cities. These are some of the key drivers of urban development, determining the functioning of the urban population, communication, leisure, business, and organization of work [Townsend 2013]. The emergence of ICT has allowed to increase the capacity of computing and reduce manufacturing costs, resulting in the introduction of new products and business models. The introduction of ICT in cities allows, among others, to increase the efficiency of the communication infrastructure, optimize the consumption of utilities supplied to residents and organizations operating in cities, and reduce administrative costs and to optimize urbanization processes. The implementation of new communication and information technologies has become an impulse to create smart city solutions. A summary of premise of a smart sustainable city and the consequences for urban development is presented Table 1.

\section{Sustainable cities vs. smart cities}

The concept of sustainable development has been presented in the literature of the subject and economic practice for a long time, but it has not yet been clearly defined. For the purpose of this study, sustainable development is defined as a development that meets the needs of the present generation without depriving of such ability future generations. It is based on: (1) the needs and necessity of satisfying them, (2) social, intra and intergenerational justice, and (3) limitations resulting from the natural environment. This depends on the intended shaping of the relationship between

${ }^{2}$ Many researchers at home and abroad deal with the issue of sustainable urban development. This is evidenced by the number of scientific conferences devoted to this issue, as well as the vast numbers of scientific publications. Google Scholar alone has 18700 publications, whose titles include the concept of sustainable urban development.

3 There are many networks and international organizations, such as ICLEI, C40 CCI, whose aim is to promote sustainable urban development and share experiences. 
economic growth, care for the environment and satisfying the needs of societies reflected in the quality of life [Petrişor, Petrişor 2013, p. 268]. Raising the quality of life is the immanent task of cities that meet not only the needs of the local community (entire urbanized areas) but also the business entities located in its vicinity. Therefore, paraphrasing the concept of sustainable development, it can be assumed that in the case of cities, it represents meeting the needs of the current residents without diminishing the opportunities of future generations. It is a concept that in a holistic way treats dependencies in cities, imposing not only a systematic view of the elements and phenomena occurring in cities, but also a future analysis of the processes shaping cities. These are increasingly associated with the progress of civilization and technology, recognized under the concept of a smart city.

In general, the sustainable development of cities can be referred to issues of the spatial form of the city, including technological solutions and quality of life in the city, with particular emphasis on social justice [Mierzejewska 2015, p. 7].

Both approaches include development within an administratively limited urbanized area. At the same time, it leads to the identification of only certain challenges and solutions related to sustainable urban development. This is because no city is self-sufficient and its uninterrupted functioning requires cooperation with the 'hinterland'. This is where city draws its resources from, and also where waste and pollution generated by urban residents are located. Urbanization and globalization meant that the city's facilities are not limited to adjacent areas. Products that meet the needs of the city residents are produced all over the world, which means that the city's impact on the environment is not limited within the city's administrative boundaries. Therefore, sustainable development requires a global perspective that allows assessing the global effects of the city. This approach will be in line with the already mentioned maxim of Agenda 21 "think global, act local". The assessment can be based on the consumption and production of the city. In the first case, we mean the sum of goods consumed by all city stakeholders, regardless of where they were made [European Commission]. In the second - the city's environmental impact is measured by the costs of producing a volume of goods in the city, including all connections in the supply chain. This perspective seems to be appropriate, not only for addressing global environmental problems, but also preventing inequalities in the distribution of environmental and social costs and benefits.

Sustainable urban development is associated with civilization and technology progress, understood as a smart city (Table 2).

A smart city is an innovative concept that in carefully planned cities, integrates digital infrastructure (without which everyday life is currently unimaginable) to ensure accessibility, environmental friendliness, resource efficiency and safety management. Many cities want to be smart, but is the will alone enough to meet the social, ecological and economic challenges of the future? What should be done to meet a smart city's criteria? These are the questions with no easy or even clear answer. In the last few years, the approach to a smart city has changed dramatically. 
Table 2. Selected definitions of smart city

\begin{tabular}{|l|l|}
\hline \multicolumn{1}{|c|}{ Author } & \multicolumn{1}{c|}{ Definition } \\
\hline $\begin{array}{l}\text { Anthony } \\
\text { Townsend }\end{array}$ & $\begin{array}{l}\text { places where information technology is combined with infrastructure, } \\
\text { architecture, everyday objects, and even our own bodies to address social, } \\
\text { economic and environmental problems }\end{array}$ \\
\hline $\begin{array}{l}\text { Andrea Caragliu, } \\
\text { Chiara del Bo, } \\
\text { Peter Nijkamp }\end{array}$ & $\begin{array}{l}\text { a "Smart city" is intended as an urban environment which, supported by } \\
\text { pervasive ICT systems, is able to offer advanced and innovative services to } \\
\text { citizens in order to improve the overall quality of their life }\end{array}$ \\
\hline $\begin{array}{l}\text { Allwinkle, S., } \\
\text { Cruickshank, P }\end{array}$ & $\begin{array}{l}\text { when investments in human and social capital and traditional (transport) and } \\
\text { modern (ICT) communication infrastructure fuel sustainable economic growth } \\
\text { and a high quality of life, with a wise management of natural resources, } \\
\text { through participatory governance }\end{array}$ \\
\hline
\end{tabular}

Source: [Townsend 2013, p. 15; Caragliu et al. 2009, p. 169; Allwinkle, Cruickshank 2011, p. 50].

Initially, smart cities were those that implemented new technologies, and innovative solutions were stimulated by private sector entities such as GE, IBM, Siemens or Cisco Systems. With time, cities understood that technology is only a tool for achieving the objectives of economic and social development. Today, the residents play a key role. Thus, a smart city is a concept that listens to the needs of residents and naturally adapts to them. Technologies in the city serve people, providing them with comfort, security and improving their quality of life. Referring to the model of a smart city developed by scientists from the Vienna University of Technology, six areas can be distinguished that are largely identical with the dimensions of sustainable development: smart economy, smart environment, smart people, smart governance, smart living and smart mobility. The last one represents communication accessibility, ICT infrastructure and innovative transport systems.

A smart city is a structure that uses modern technologies and communication tools to manage the big data, and with that improve the functioning of the city and the quality of life in it. However, intelligent sensors, the Internet of Things ${ }^{4}$ and software are not enough. Nowadays the needs and preferences of the residents are of high importance, and the technology is there to meet them. These changes indicate the evolution of the intelligent city concept. According to B. Cohen, we can distinguish three generations of a smart city: (1) inspired by available technologies, (2) with the dominance of public administration initiating the implementation of new technologies and (3) based on the creative involvement of residents [Fastcompany]. The first generation, which adheres to the "must have" philosophy, namely, a vision of a city controlled and driven by the private sector, loses the key issue of its functioning, namely the relations and interactions of the city with its the residents. Therefore, future-oriented authorities took the initiative and became the leaders of change and partners of technology suppliers (second generation). They determine

\footnotetext{
${ }^{4}$ For more on the Internet of Things in the context of a smart city, see [Szołtysek 2018].
} 
the directions of development, the scope of implemented innovations and technological solutions, and although these solutions undoubtedly facilitate life in the city, they will not be able to fulfill their role in isolation from the social context. That is why R. Robinson appeals to the need of mutual implementation of the vision of cities in the future - top-down, implemented by authorities and bottom-up controlled by citizens [Robinson 2015]. If a city wants to be truly smart, it must take into account the needs of all stakeholders (residents, entrepreneurs, non-profit organizations, etc.). Being smart (third generation) requires investment in human and social capital. Social participation and the cooperation of public administration with social and business partners are necessary for achieving success. In this perspective a smart city is a common space belonging to the community that lives in it, which has the right to meet its social and ecological needs. Thus, a smart city is a city that operates in a sustainable way - it is a smart sustainable city. Its implementation requires bottom-up initiatives, involving numerous groups of residents whose goal is not only to improve the city's functioning, but also achieve its transformation.

Khansari, Mostashari and Mansouri even claim that a smart city is the modern version of a sustainable city (2013: 46). To put it simply, it could be assumed that a smart city is a sustainable city. Is it not enough to use the concept of smart city without the adjective sustainable? The author thinks not. This is because not every sustainable city has to be smart and vice versa. One can only talk about smart sustainable city when smart technologies serve all stakeholders and the environment. The European Parliament report on smart city mapping in the EU shows that the most common activities and initiatives in smart cities included smart environmental (33\%) and smart mobility (21\%) [European Parliament].

A smart sustainable city describes a city whose development is supported by modern technologies and co-created by residents. It is a concept assuming the improvement of the quality of life in the city while reducing the negative impact on the environment and resulting in the more efficient use of natural resources.

A smart sustainable city is a city that is a kind of joint venture of many social partners, using the richness of the diversity of knowledge and roles in which individual local residents occur [Castelnovo et al. 2015]. This reflects the continuous transformation process, based on the involvement and cooperation of stakeholders and building various types of potential: human, institutional, and technological. It allows for the improvement of the quality of life of residents through socioeconomic development and the protection of natural resources.

The significance and importance of the development of a smart sustainable city is reflected in the initiative of the European Commission - the European Innovation Partnership on Smart Cities and Communities. This program integrates key city stakeholders around creating smart solutions in the areas of energy, technology and transport. The latter one plays a key role in the functioning of contemporary socioeconomic systems. It is also one of the most dynamically developing sectors of the economy. Transport is a crucial condition for undisturbed mobility. However, it 
causes substantial environmental burdens, congestion, noise pollution and the overload of the transportation infrastructure, which inevitably leads to a decline in the quality of life. The research quoted earlier shows that in smart cities, actions for sustainable mobility are among the most frequently undertaken. This shows the importance of the problem in creating a smart sustainable city whose parameters are presented in Table 3.

Table 3. The key parameters of a smart and sustainable city

\begin{tabular}{|c|c|}
\hline $\mathrm{Sm}$ & Susta \\
\hline $\begin{array}{l}\text { - Smart Economy - competitiveness, } \\
\text { innovation, productivity, entrepreneurship, } \\
\text { labour market flexibility, international } \\
\text { investments, capital involvement } \\
\text { - Smart Mobility - access to modern } \\
\text { information and communication } \\
\text { technologies, sustainable transport systems } \\
\text { (local, intercity, international) } \\
\text { - Smart Environment - attractiveness of } \\
\text { natural assets, environmental protection, } \\
\text { management of natural resources, degree } \\
\text { of environmental pollution, ecological } \\
\text { awareness } \\
\text { - Smart People - citizens' qualifications } \\
\text { and education level, ability to increase } \\
\text { knowledge, creativity, quality of social } \\
\text { interactions, openness to the external world, } \\
\text { social and cultural diversity, participation in } \\
\text { public life } \\
\text { - Smart Living - culture, education, lifelong } \\
\text { learning, conditions and comfort of living, } \\
\text { personal safety, health conditions, social } \\
\text { integration, tourist attractiveness } \\
\text { - Smart Governance - functioning of } \\
\text { the administration, transparency of } \\
\text { management, policies and prospects, the } \\
\text { development of socialization }\end{array}$ & $\begin{array}{l}\text { - Social development, including quality of life } \\
\text { - public transport available to residents, the } \\
\text { dominance of the extensive public transport } \\
\text { network, cycling and walking, access to } \\
\text { health care and education, inequalities in pay, } \\
\text { balance between work and private life, number } \\
\text { of professionally active people against the } \\
\text { number of professionally inactive, supporting } \\
\text { the fight against social exclusion, promoting } \\
\text { organic farming and supporting local farms, } \\
\text { green areas } \\
\text { Environmental impact - energy consumption } \\
\text { and share of energy from renewable sources, } \\
\text { e-mobility, energy democracy, greening of } \\
\text { energy, reduction of the occurrence of heat } \\
\text { islands } \text {, greenhouse gas emissions, recycling, } \\
\text { risk of natural disasters, air pollution, access to } \\
\text { drinking water and sanitation } \\
\text { Compact spatial structure - concentration and } \\
\text { density, polycentric urban structure, access to } \\
\text { local services and jobs, highly corroded street } \\
\text { connections system } \\
\text { Economic development potential - transport } \\
\text { infrastructure, ease of doing business, city } \\
\text { location in the global economy network, } \\
\text { real estate prices and cost of living, GDP per } \\
\text { capita, energy efficiency }\end{array}$ \\
\hline
\end{tabular}

a) Urban heat island - a meteorological phenomenon involving the thermal privilege of urban space relative to surrounding undeveloped areas.

Source: own study.

The characteristics in the table are the basis of a comparative analysis of cities recognized for their intelligence and sustainability. The first one was carried out periodically in the Vienna University of Technology, Department of Spatial Planning SRF. The latest edition of the European Smart Cities 4.0 study included an assessment of cities with a population from 300,000 to 1 million inhabitants. Detailed data can 
be found in the Eurostat Urban Audit database. However, the ranking of the most sustainable cities in the world was developed by Arcadis, which surveyed 50 cities from 31 countries around the world while preparing the report, e.g. data from the $\mathrm{UN}$, the World Bank, the WHO, and the International Labour Organization (ILO).

\section{Smart mobility as an expression of a smart sustainable city}

The need for sustainable mobility results from the idea of a smart sustainable city, which should be a city for the public [Szołtysek 2018], and sustainable transport systems are inscribed in the idea of smart mobility. These are some of its key elements and indicators [Giffinger et al. 2007]. In a smart sustainable city, thoughtful and efficient traffic management meets the needs of various groups of stakeholders who are the users of the city's infrastructure. In order for it to be efficiently implemented it requires support from ICT solutions. These, thanks to extensive transport and communication systems [Stawasz et al. 2012, p. 100], allow connecting all of the resources of the city. Thus it is possible to monitor and control the fleet, access realtime information from users, and even plan the travel. Technological solutions such as telematics form the basis for the development of intelligent transportation systems. Their goal is to support the supervision, control and management of transportation processes. Thanks to smart technologies, traffic managers can make measurements and forecast users' behaviour. Thus, smart solutions determine movement optimization, increase traffic safety and reduce external transport costs.

Smart mobility supports sustainable mobility, reduces greenhouse gas emissions and noise pollution not only through the increase in transport efficiency but also through the use of more energy-efficient vehicles or working with "ecological" carriers. In cities, electric vehicles and charging stations are part of a modern transportation system that allows for a significant reduction in greenhouse gas emissions. Smart mobility creates the basis of implementation into urban traffic of vehicles that communicate with each other, and a person traffic managing can make measurements and forecast their behavior. GPS data (for example speed and location) that are sourced in real time are the basis of optimizing of movements. Studies of communicative vehicles show many new possibilities in the area of a better use of a supply train adapted to individual orders, predictable and always ready to drive. Through communication systems such V2V (Vehicle to Vehicle) and V2I - (Vehicle to Infrastructure) connection can prevent traffic jams, reduce fuel consumption and emissions of exhaust fumes and also reduce the number of car accidents. The Audi project, Travolution, is an example for such implementations, whose main concept is vehicle communication with traffic lights through a mobile net. Thanks to a set computer system it will correspond with traffic lights and will inform the driver about the speed he/she needs to have to go straight to a green light on the next crossing. In the case of a car connected to the web, the driver reduces the time, decreasing his/her standard use of fuel and as a result reduces the emission of $\mathrm{C} 02$ [Audi Travolution 2018]. 
The implementation of intelligent solutions, however, does not make our mobility sustainable. For this, it is necessary to provide various forms of mobility in the city. This determines whether we perceive the city to be attractive and friendly for everyday functioning, or not. Creating alternatives for using individual vehicles should translate into verifiable profits in the form of, for example, limiting the time needed to perform everyday mobility. Its reduction results in greater satisfaction and a noticeable increase in the quality of life in the city. Striving for smart sustainable mobility does not mean, therefore, the expansion of transport infrastructure and the construction of subsequent road lanes, but in the efficient usability of space and the creation of real alternatives to individual transportation. It gives a chance for a qualitative change, namely, improving the quality of the natural environment and life in the city. The key indicators of intelligent mobility include:

- accessibility, including the adequacy of the transport network to the number of population;

- satisfaction with the availability and quality of public transport;

- innovative and secure transport systems, including the participation of green mobility (non-motorized individual transport);

- transport security;

- the use of economical and low-carbon cars.

Smart sustainable mobility reflects the pursuit of multimodal transport systems with high flexibility and convenience for residents, based on intelligent management (Mobility-as-a-service, MaaS). It is a concept in which passengers' needs are met with one service, combining the services offered by many carriers, navigation systems and payment technologies. The customer can usually use such a combined package using a dedicated app (geographical).

Helsinki ${ }^{5}$, where the Whim app has been operating since January 2017, is a pioneer in implementing Maas worldwide. Application developers managed to encourage the cooperation public and private sector entities. Whim users have the option of using various forms of public transport (streetcar, bus, metro), taxis and car rentals. It is planned to expand the scope of application functionality with city bikes, trains and intercity buses (Netflix). Helsinki is planning to eliminate city traffic by 2050 , not by prohibitions but by the creation of such a transport system that will make the car becomes redundant.

For the city, the result of the spread of the MaaS concept is to reduce congestion, the number of cars owned by residents, increase the number of public transport passengers, and promote environmental protection by reducing pollutant emissions. These assumptions are confirmed by tests of the Viennese Smile app, which took place in 2014. Thanks to the app, users could combine many types of transport in one trip, including trains, public transport, short-term car and bicycle rentals, and even

\footnotetext{
${ }^{5}$ This application also functions in the West Midlands in Great Britain.
} 
a ferry from Vienna to Bratislava ${ }^{6}$. Public health experts argue that the Whim app encourages healthier choices, such as walking and cycling.

The Polish market of services from the MaaS family can be briefly characterized as very diverse, as there are the services from this family themselves. There are many applications on the Polish market that allow one to buy tickets for a tram or bus. There are systems that allow short-term bike rentals or car rentals (res.cloudinary).

\section{Social participation as a condition of implementing of smart sustainable mobility}

Social participation is an important element in the creation of smart sustainable mobility, an indispensable element of a sustainable urban mobility plan. Such a plan is a document of strategic importance, elaborated and implemented by city authorities and entities involved in the implementation of transport policy. The main goal of SUMP is to strive to improve the quality of life of urban residents and reduce the negative impact of transport on the environment (European Commission). The main distinguishing feature of the plan is the extensive involvement of stakeholders, going far beyond the scope of traditionally understood social consultations. The inclusion of stakeholders in planning activities requires the identification of the most influential ones both on the demand and supply side of the transport market. Great Britain is a pioneer in implementing SUMP, where since the year 2000, local authorities have been obliged to adopt and implement Local Transport Plans. Every five years it is recommended to assess the degree of their implementation. An example of a local transport plan is the document adopted by West Yorkshire". The goals of the "My Journey West Yorkshire" plan are to reduce emissions, improve the business environment and improve the quality of life for residents. These goals have been subordinated to mobility goals, such as reducing travel time, reducing transport congestion, improving safety, priorities for public transport and improving the efficiency of public spending [West Yorkshire Transport Plan].

In France the first transport plan was also adopted in 2000. As part of the measures to increase the attractiveness of public transport, a BRT (Bus Rapid Transit) system was introduced in 2006 based on the separation of road infrastructure exclusively for high-frequency buses and integration nodes with the most important high capacity stops for cars. The main characteristics of the system, called "BusWay", are high frequency, communication speed and availability, taking into account the needs of passenger car users. An additional goal of the transport plan for Nantes was to reduce emissions, which was expressed by the gasification of a significant number of buses and the gradual introduction of hybrid buses [Wołek 2014, p. 395].

${ }^{6} 1000$ respondents took part in the tests, and declared more frequent use of public transport (26\%) and rail transport (22\%) and a reduction in their own car trips $(21 \%)$.

${ }^{7}$ Adopted in 2011 and effective until 2026. 
In Poland, on 15 April 2019, a conference launched a pilot project under which the Ministry of Investment and Development, the Ministry of Infrastructure, the Centre for EU Transport Projects and the EU initiative JASPERS, which supports entities using EU funds, will help cities to prepare sustainable urban mobility plans; 37 cities have signed up for the project. Direct cooperation with JASPERS was selected by five of them: Rawicz, Konin, Bialystok area Functional, Functional Area Gdansk-Gdynia-Sopot sub-region and the Central Region of Silesia. The remaining 32 cities that have expressed interest in the subject of SUMP will have the opportunity to participate in free workshops. During the meetings, the results of the work with the selected five cities will be presented to show both the good practices and pitfalls during the SUMP implementation (Pois).

Frequently, a participatory approach is achieved by providing a number of communication channels and intelligent internet platforms that allow for the sharing of big data. In the smart sustainable city, the question of the platform can be considered in two ways: (1) a smart sustainable city as a whole can be treated as a platform for establishing city-to-town relations; (2) the city becomes intelligent only with the support of internet platforms, that offer a wide range of services and access to large data sets that are the basis for making decisions in line with residents' expectations. Regardless of how online platforms are understood, the collection and processing of data is an important resource that influences the market dynamics. As a result, the larger the collection of data on the mobility behavior of stakeholders, the better the city can adapt its transportation package to their needs. The collection of data, however, requires social participation, as it is the residents and private entities that have valuable information for the city. For example, effective traffic management in a city is possible only on the basis of data analysis that may be in possession of private companies (e.g. Uber), social networks, car rental agencies, and come from devices and sensors assembled by cities.

The participatory angle of a smart sustainable city fits perfectly with the sharing economy [Kauf 2018], because the nature of urban space inclines to the sharing of resources and rare goods. Cities are in fact "natural sharing economies - limited space and high population density are conducive to shared consumption as a consequence of easy access to shared resources" [Sundararajan 2014]. Smart cities are those that use technologies to build urban cities $^{8}$, based on the economy of sharing. Vast sharing potential exists in the area of mobility. Such potential is understood as sharing mobility (bike sharing, car sharing) that allows for a reduction in congestion and greenhouse gas emissions. Thanks to shared mobility, it is possible to "give" the city's space to its residents - freeing public space from the dominance of cars, without having to give up "door to door" travel. Sharing mobility significantly affects the reduction of the number of vehicles necessary to travel in urban areas, and thus significantly reduces the emission of toxic substances into the environment.

\footnotetext{
${ }^{8}$ Urban cities are understood as the creation of the city that is conducive to social use, with an attractive functional program.
} 
Sharing concepts open up new mobility opportunities for people with limited financial resources, and support from cities in the field of car sharing, commuting to work and even bus travel is becoming an important element in creating sustainable cities. Apps provided by the city for travel planning and paying transportation fees can positively influence the integration of shared transport with public transport, especially at interchanges and city centres. Smart technology helps suppliers of products and services to meet with people interested in using them. A sharing economy offers a large amount of data that authorities can use to quickly (even in real time) respond to a changing environment. As a result, the relationship between sharing mobility and a smart sustainable city is two-way. Thus, it is tempting to state that shared mobility is the future of smart cities and an effective way to sustain their development.

\section{Conclusion}

Creating smart sustainable cities places their authorities in front of big challenges. One of them is striving for sustainable mobility, namely the preference for alternative forms of transport to individual transportation. The significance and importance of mobility in the efficient functioning of cities makes smart mobility a key determinant of success for smart sustainable cities. This is the goal that city authorities are heading towards. Providing the possibility to use various forms of transportation influences the assessment of the attractiveness of the city and translates into specific benefits, for example, in the form of larger amounts of time which can be used better.

Sustainable mobility allows to limit traffic in the city, thus reducing the negative impact of transport on the natural environment (emissions and noise pollution). The full use of smart mobility potential, however, requires social participation, manifested by shared mobility. This is the undisputed tool for creating smart sustainable cities, as it reflects the co-creation of mobility by its residents. However, sustainable cities of the future cannot develop without mobile technologies, social communication and developing on-line platforms supporting direct cooperation between people, and thus facilitating the development of smart sustainable cities.

\section{Bibliography}

Allwinkle S., Cruickshank P., 2011, Creating smarter cities - an overview, Journal of Urban Technology, no 18(2).

Audi Travolution 2015, http://www.gadgetreview.com/audi-travolution-project-predicts-red-trafficlights, (08.02.2018).

Caragliu A., del Bo C., Nijkamp P., 2009, Smart Cities in Europe, Proc. of Central European Conf. in Regional Science, CERS, Kaschau, Slovakia.

Castelnovo W., Misuraca G., Savoldelli A., 2015, Smart cities governance: The need for a holistic approach to assessing urban participatory policy making, Social Science Computer Review, vol. 34, pp. 1-16, https://www.researchgate.net/publication/284859012_Smart_Cities_Governance_The Needfor_a_Holistic_Approach_to_Assessing_Urban_Participatory_Policy_Making (11.06.2019). 
European Commision, https://ec.europa.eu/digital-agenda/en/about-smart-cities (19.08.2019).

Esa, 2018, https://esa.un.org/unpd/wup/ (03.09.2018).

European Commission, Together towards competitive and resource-efficient urban mobility, COM/2013 913 final, Brussels, 17.12.2013.

European Parliament: Mapping Smart Cities in the EU. Policy Dep. A: Economic and Scientific Policy. IP/A/ITRE/ST/2013-02， http://www.europarl.europa.eu/RegData/etudes/etudes/join/ 2014/507 480/IPOL-ITRE ET(2014)507480 EN.pdf(17.08.2019).

Fastcompany, https://www.fastcompany.com/3047795/the-3-generations-of-smart-cities (15.05.2019). Geographia, https://geographica.com/en/blog/what-is-smart-mobility/ (17.08.2019).

Giffinger R., Fertner C., Kramar H., Kalasek R., Pichler-Milanović N., Meijers E., 2007, Smart Cities: Ranking of European Medium-Sized Cities, Centre of Regional Science (SRF), Vienna University of Technology, Vienna.

Kauf S., 2018, Ekonomia współdzielenia (sharing economy) jako narzędzie kreowania smart city, Zeszyty Naukowe Politechniki Śląskiej, pp. 141-151.

Khansari N., Mostashari A., Mansouri M., 2013, Impacting sustainable behaviour and planning in smart city, International Journal of Sustainable Land Use and Urban Planning, vol. 1, no 2, pp. 46-61, https://www.sciencetarget.com/Journal/index.php/IJSLUP/article/viewFile/365/ 104 (19.05.2019).

Mierzejewska L., 2015, Zrównoważony rozwój miasta - wybrane sposoby pojmowania, koncepcje $i$ modele, Problemy Rozwoju Miast, no 3.

Netflix, Is Whim the Netflix of mobility?; https://helsinkismart.fi/portfolio-items/whim/

Petrişor A.I., Petrişor L.E., 2013, The shifting relationship between urban and spatial planning and the protection of the environment: Romania as a case study, Present Environment and Sustainable Development, no 7 (1), pp. 268-279.

Pois, https://www.pois.gov.pl/strony/o-programie/plan-zrownowazonej-mobilnosci-miejskiej-sump/ aktu-alnosci/37-miast-chce-wdrazac-plan-zrownowazonej-mobilnosci-miejskiej/ (12.05.2018).

res.cloudinary, Mobility as a Service PL. Pierwszy przekrojowy raport z polskiego rynku MaaS, https:// res.cloudinary.com/dikm0e8eo/image/upload/v1539877688/Mobility-as-a-Service-PL-Raport-Straal.pdf (21.07.2018).

Robinson R., 2015, Reclaiming the "Smart" agenda for fair human outcomes enabled by technology, The Urban Technologist, pp. 82-90, http://theurbantechnologist.com/2015/03/20/ reclaiming-thesmartagenda-for-fair-human-outcomes-enabled -by-technology (17.08.2019).

Stawasz D., Sikora-Fernandez D., Turała M., 2012, Koncepcja smart city jako wyznacznik podejmowania decyzji zwiazanych z funkcjonowaniem i rozwojem miasta, Zeszyty Naukowe Uniwersytetu Szczecińskiego, nr 721, Studia Informatica, nr 29, pp. 97-109.

Sundararajan A., 2014, Peer-to-Peer Businesses and the Sharing (Collaborative) Economy: Overview, Economic Effects and Regulatory Issues, Committee on Small Business of the United States House of Representatives, January 15th, http://smallbusiness. house.gov/uploadedfiles/1-15-2014_revised_Sundararajan_testimony. pdf.

Szołtysek J., 2018, Miasto w dobie internet of Things, [in:] Ł. Sułkowski, D. Kaczorowska-Spychalska (eds.), Internet of Things. Nowy paradygmat rynku, Difin, Warszawa.

Townsend A., 2013, Smart Cities - Big Data, Civic Hackers and the Quest for a New Utopia, Norton \& Company, New York.

Transport publiczny, https://www.transport-publiczny.pl/wiadomosci/mobility-as-a-service--ewol-ucja-w-poruszaniu-sie-po-miescie-54074.html (14.07.2019).

West Yorkshire Transport Plan, http://www.wyltp.com/NR/rdonlyres/1CF40EA9-62D8-4611-964EC6D1B663628E/0/20121003LTPFullStrategy.pdf (3.08.2018).

Wołek M., 2014, SUMP (Sustainable Urban Mobility Plan) jako narzędzie kształtowania zrównoważonej mobilności miejskiej, „Logistyka-nauka”, no 2. 